\title{
FRUIT YIELD AND QUALITY OF DRIP-IRRIGATED TOMATO UNDER DEFICIT IRRIGATION
}

\section{Birhanu $\mathrm{K}^{1}$ and $\mathrm{K}$ Tilahun ${ }^{* 1,2}$}

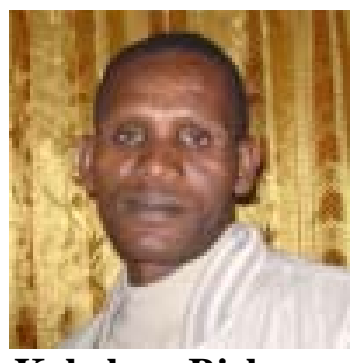

Kebebew Birhanu

*Corresponding author email: ketematilahun@yahoo.com

${ }^{1}$ Haramaya University, P. O. Box 45, Haramaya University, Ethiopia

${ }^{2}$ School of Agricultural and Wine Sciences, Charles Sturt University, Wagga Wagga, NSW, Australia. 


\section{ABSTRACT}

The competition for limited amount of world fresh water is increasing at a fast rate. The agricultural sector is the major water user and also the most inefficient. As a result, the economic return from a unit of water is the lowest for agricultural sector. Therefore, in the wake of dwindling water availability, it is becoming imperative to look for ways of maximizing yield and quality of produce per unit of water. This is especially important in countries like Ethiopia, where there is severe water shortage in the arid and semi-arid areas. In this study, a field experiment was conducted at Melkassa Agricultural Research Center, Ethiopia to study the effects of moisture stress on the yield and quality of two tomato cultivars; Melka Shola and Melkassa Marglobe used as salad. The two tomato cultivars were exposed to four irrigation water deficit levels expressed as percentages of potential evapotranspiration (ETc) as: $0 \% \mathrm{ETc}, 25 \% \mathrm{ETc}, 50 \% \mathrm{ETc}$, and $75 \% \mathrm{ETc}$ deficit. The total plant biomass decreased with stress level while the fruit dry matter increased. As a result, the harvest index (fruit dry matter weight/plant dry matter weight) was increased with stress level. At a given stress level, the harvest index of Melka Shola was higher than that of Melkassa Marglobe. Both the number and size of tomato fruits were found to decrease with moisture stress. The incidence of sun-scald and blossom end rot was higher in the more stressed plants $(75 \%$ ETc) deficit. The total soluble solid (TSS) content was significantly affected by irrigation treatments. The total soluble content was increased with stress level while the fruit water content was decreased. The fruit total soluble content (TSS) of the stressed plants was also significantly different between the tomato cultivars. Melkassa Marglobe cultivar had higher total soluble solute content than Melka Shola cultivar. The higher total soluble solute content of Melkassa Marglobe might be the reason why this cultivar is preferred by consumers for use as a salad. It has been observed also that small animals and birds fed more on this cultivar than on the Melka Shola cultivar.

Key words: deficit irrigation, quality, tomato, yield 


\section{INTRODUCTION}

Tomato is one of the most widely grown vegetables in the world. Tomato plants are sensitive to water stress and show high correlation between evapotranspiration and crop yield [1]. In many parts of the world, tomato is produced under irrigation [2, 3]. However, due to the global expansion of irrigated areas and the limited availability of irrigation water, there is need to optimize water use in order to maximize crop yields under water deficit conditions [4].

Designs of irrigation schemes usually do not address situations in which moisture availability is the major constraint on crop yields. However, under limited water availability, optimal irrigation management and scheduling are necessary in order to increase the efficient use of water for agriculture. Agronomic measures such as varying tillage practices, mulching and use of anti-transpirants can reduce demand for water. Another option is deficit irrigation: exposing the plant to a certain level of water stress during a particular growing period, or throughout the whole growing season, without significant reduction in yield [5,6]. Although the effects on yield may be different, many of the research results have shown that regulated deficit irrigation saves substantial amounts of irrigation water and increases water use efficiency [7,8]. Still other options are use of drip irrigation and partial root drying $[9,10,11,12,13]$.

With drip irrigation, precise water application is possible, improving efficiency. Drip irrigation is used for vegetable production in areas where water is scarce or expensive [14]. Although high yields of tomato (Lycopersicon esculentum Mill.) have been recorded after switching to drip irrigation, the gains in yield can be offset by lower fruit quality than is obtained with furrow and sprinkler irrigation, especially if the crop is infrequently stressed between irrigations, or if the crop is irrigated too close to harvest $[15,16,17,18,19]$. Although growth can be affected due to water stress, fruit quality parameters such as total soluble solids usually improve [20]. In addition, overstressing the crop to obtain high brix levels can significantly reduce fruit yields and the benefits of using drip irrigation. Growers are challenged with optimizing brix levels of fruit to meet processors' needs and with maximizing yields to maintain the profitability of their operations.

The landholding of Ethiopian farmers is so much fragmented with most farmers owning a piece of land less than a hectare. The rainfall pattern is so erratic and intensive throughout when it rains. Currently, it is being tried to harvest rain water using different water harvesting structures and using it in combination with gravity drip system. This is useful especially for vegetable production which can augment farmers' income and nutritional intake. This study was undertaken to determine the effects of irrigation quantities on fruit yield and quality of field grown, drip-irrigated tomatoes. 


\section{MATERIALS AND METHODS}

The study was conducted at Melkassa Agricultural Research Center in the Central Rift Valley of Ethiopia, located at $8^{\circ} 24^{\prime} \mathrm{N}$ latitude and $39^{\circ} 21^{\prime} \mathrm{E}$ longitude, having an elevation of $1552 \mathrm{~m}$ above mean sea level. Mean annual rainfall is $950 \mathrm{~mm}$ with erratic occurrence. Mean maximum and minimum temperatures are $28^{\circ} \mathrm{C}$ and $14^{\circ} \mathrm{C}$, respectively. The soil is a loam (sand $37 \%$, silt $42 \%$, and clay $21 \%$ ). The field capacity and permanent wilting point of the soil are $38 \%$ and $22 \%$, respectively.

Tomato seeds were sown on September 18, 2005 on seed beds. The seedlings were transplanted on October 18, 2005 after completing initial growth stage (that is 30 days). Rainfall was harvested and stored in an underground cistern. The water was pumped using a treadle pump into an elevated tank, 1000 liters capacity, at a height of $1.5 \mathrm{~m}$. Water was applied to the crops using a gravity drip system.

The experimental design of the trial was spilt plot with four level of irrigation deficit level $(0 \%, 25 \%, 50 \%$ and $75 \%)$ assigned as main plot and two tomato varieties (Melka Shola and Melkassa Marglob) to subplot. The two cultivars, Melka Sholasemi-determinate and Melkassa Marglobe-indeterminate, were transplanted with spacing of $0.3 \mathrm{~m}$ between plants and $0.8 \mathrm{~m}$ between rows to plots of $3 \mathrm{~m} \times 5 \mathrm{~m}$. Each treatment plot consisted of four rows of tomato with a total of 68 plants per plot. Irrigation was applied at three day intervals. Fertilizer DAP was side dressed at a rate of $200 \mathrm{~kg} / \mathrm{ha}$ at transplanting and $100 \mathrm{~kg} / \mathrm{ha}$ urea was applied in splits at transplanting and 45 days after transplanting. To protect the crop from disease infestation, Ridomil Gold RZ was applied at a rate of $3.5 \mathrm{~kg} / \mathrm{ha}$. For insect protection, Cypermethin or Karate was used at a rate of $100 \mathrm{~g} / \mathrm{ha}$.

Crop evapotranspiration was determined using FAO Penman-Monteith method [21] (Eq. 1) with the weather data recorded at the weather station of the Research Center and the tomato crop coefficient (Kc) obtained from literature [22].

$$
\mathrm{ETo}=\frac{0.408 \Delta\left(R_{n}-G\right)+\gamma \frac{900}{T+273} \times U_{2}\left(e_{a}-e_{d}\right)}{\left[\Delta+\gamma\left(1+0.34 U_{2}\right)\right]}
$$

Where ETo $=$ reference crop evapotranspiration $\left(\mathrm{mm} /\right.$ day), $\mathrm{R}_{\mathrm{n}}=$ net radiation at crop surface $\left(\mathrm{MJ} / \mathrm{m}^{2} /\right.$ day $), \mathrm{G}=$ soil heat flux $\left(\mathrm{MJ} / \mathrm{m}^{2} /\right.$ day $), \mathrm{T}=$ average temperature $\left({ }^{\circ} \mathrm{C}\right)$, $\mathrm{U}_{2}=$ wind speed measured at $2 \mathrm{~m}$ above ground $(\mathrm{m} / \mathrm{s}), \mathrm{e}_{\mathrm{a}}-\mathrm{e}_{\mathrm{d}}=$ vapor pressure deficit (kpa), $\Delta=$ slope vapor pressure curve $\left(\mathrm{kPa} /{ }^{\circ} \mathrm{C}\right), \gamma=$ psychometric constant $\left(\mathrm{kPa} /{ }^{\circ} \mathrm{C}\right)$, $900=$ conversion factor.

The crop evapotranspiration (ETc) was determined as:

$$
E T c=E T o^{*} K c
$$


The amount of irrigation water applied to the four treatments was: 100\%ETc (or $0 \%$ ETc deficit), $75 \%$ ETc (or 25\%ETc deficit), 50\%ETc (or 50\%ETc deficit), and $25 \%$ ETc (or $75 \%$ ETc deficit).

For the purpose of crop data collection, two plants were tagged per row, eight plants per plot for both cultivars. Plant heights were measured once every week starting from the beginning of the deficit irrigation treatment (October 27, 2005) to the end of the midseason stage (January 8, 2005). Numbers of fruit/plant were taken towards the end of the late season (January 15, 2005) and average number of fruit/plant for each treatment determined. The two middle rows of each treatment plot were harvested at the end of the season (January 23, 2005). Fruits were weighed to estimate total yield and five kilogram subsamples sorted into marketable and cull. Marketable fruits were sorted as extra-large, large, medium, and small based on their weight, as presented in Table 1.

Mature plants were selected at random from the two external rows of each plot on January 21, 2005. The above-ground plant biomass was sorted into shoot and fruit for fresh and dry weight determination. Since only the two middle rows of each plot were used for yield estimation and extrapolated to total area of each treatment, the fruit of plants taken at two external rows did not have effect on yield. For the water content and total soluble solid content analysis, one kilogram sample of red fruit were collected at random from the two external rows of each plot before final harvest. Each sample was washed, dried, blended, and poured through a laboratory pulper with a 0.33 mesh screen to remove seed and skin. Water content was determined using an automatic volatility computer (model 340, CEM, London, UK). Sub samples were filtered and serum used for soluble solid content determination with a digital refractrometer (model 340, REM, London, UK).

Analysis of variance for the design was carried out for the parameters studied following the standard procedures applicable to split plot design [23]. When the treatment effects were found significant, mean differences were tested using Duncan's Multiple Range Test (DMRT) at $5 \%$ or $1 \%$ level of probability. Analysis of variance was computed using the MSTATC software package.

\section{RESULTS}

Prior to the initiation of irrigation treatments, $67 \mathrm{~mm}$ of water was applied equally to each treatment. The total amount of irrigation water applied to each treatment was calculated as the sum of water applied during the crop establishment period and the ETc of the remaining period. The amount of irrigation water applied during the latter period was $528 \mathrm{~mm}$ for the $0 \% \mathrm{ETc}$ deficit level treatment, $400 \mathrm{~mm}$ for the $25 \% \mathrm{ETc}$ deficit level treatment, $264 \mathrm{~mm}$ for the $50 \%$ ETc deficit level treatment, and $132 \mathrm{~mm}$ for the $75 \%$ ETc deficit level treatment. The total amount of irrigation is, therefore, $595 \mathrm{~mm}, 467 \mathrm{~mm}, 331 \mathrm{~mm}$, and $199 \mathrm{~mm}$ for the 0\%ETc deficit, 25\%ETc deficit, $50 \%$ ETc deficit, and $75 \%$ ETc deficit treatments, respectively. 
Total plant fresh biomass (shoot and fruit weight) at maturity of both tomato cultivars was significantly affected by irrigation water applied. Both shoot and fruit weight loss was decreased with increase in stress level. Irrigation treatments which received $25 \%, 50 \%$, and $75 \%$ of the full irrigation requirement resulted in $13.2 \%, 45.0 \%$, and $59.0 \%$ total fresh biomass reduction respectively (Table 2). However, there was nonsignificant difference between the cultivars. The interaction effect of $=$ of irrigation deficit and tomato cultivars was non-significant. While shoot dry weight consistently decreased with increase in stress level, the fruit dry matter weight increased. The fruit dry matter increased by $29.1 \%, 37.9 \%$, and $39.3 \%$ for Melka Shola cultivar and $17.2 \%, 19.3 \%$, and $23.9 \%$ for Melkassa Marglobe, respectively at 25\%, 50\%, $75 \%$ deficit levels relative to the non-stressed treatment (that is, $0 \%$ deficit level). There was a significant difference between the cultivars regarding shoot and fruit dry weights (Table 4). However, there was a non-significant difference for the interaction effect of cultivar and irrigation.

The harvest indices HI (which is fruit dry matter weight per plant dry weight) were significantly affected by irrigation deficit levels. As shown in Table 3, the harvest index was higher for more stressed tomatoes of both cultivars, an indication of high dry matter accumulation as the crop was stressed. Such trend has also been observed for groundnut in other studies [24]. However, there was non-significant difference between the cultivars.

The number of fruits per plant was affected both by water deficit level and cultivars (Table 3). Fruit size as well as number of fruits per plant was reduced with reduction in the amount of irrigation water applied for both cultivars. The difference between the cultivars was significant with Melka Shola cultivar consistently having more number of fruits per plant and lower fruit size compared with that of Melkassa Marglobe. The number of smallest fruit size of both tomato cultivars was lower at higher water stress levels (Table 3). Melka Shola cultivar produced significantly lower smallest fruit size than that of Melkassa Marglobe. The interaction effect of cultivar and irrigation was also significant.

Irrigation positively influenced tomato productivity. The result was due both to the increase in number of berries per plant and the fruit average weight as irrigation increased. The total yield and marketable yields were significantly decreasing as the deficit level was increased. However, the difference between the cultivars and the interaction effect was non-significant (Table 5). The yield amounted to $45.1 \mathrm{t} / \mathrm{ha}$ on average for $0 \%$ deficit irrigation treatments and $18.4 \mathrm{t} / \mathrm{ha}$ for $75 \%$ deficit irrigation treatment for Melka Shola cultivar. These values were $45.2 \mathrm{t} / \mathrm{ha}$ and $13.1 \mathrm{t} / \mathrm{ha}$ for Melkassa Marglobe cultivar. At the same time, the marketable yield decreased with stress level in both cultivars. The marketable yield was $41.5 \mathrm{t} / \mathrm{ha}$ and $15.1 \mathrm{t} / \mathrm{ha}$ at $0 \%$ and $75 \%$ deficit levels, respectively for Melka Shola cultivar. These values were, respectively $41.3 \mathrm{t} / \mathrm{ha}$ and $11.2 \mathrm{t} / \mathrm{ha}$ for Melkassa Marglobe cultivar. The total and marketable yield of tomato was lowest in the most stressed treatment of $75 \%$ deficit level. 
For both tomato cultivars, the fresh fruit yields were reduced in $25 \%, 50 \%$, and $75 \%$ deficit level treatments by $6.8 \%, 48.5 \%$, and $71.0 \%$, respectively. The irrigation treatment (stress level) significantly affected the yield of tomato cultivars whereas the cultivar difference was non-significant (Table 5).

Table 6 shows that deficit irrigation treatments had pronounced effect on the soluble solute (TSS) content of the fruits. Fruit soluble solid content increased with increase in water stress. The TSS content of the most stressed treatment (75\% deficit level) increased by $2.3 \%$ for Melka Shola and $4.2 \%$ for Melkassa Marglobe relative to the respective fully irrigated treatments ( $0 \%$ deficit level).

\section{DISCUSSION}

The reduction of total yield, number of fruit per plant, fruits size, and plant biomass production with an increased amount of water stress level of this test was consistent with previous work conducted on tomato and other crops such as cotton [25, 26]. Water stress consistently reduced production of the most valuable extra-large sized fruit. A study conducted to evaluate the effect of irrigation cutback on yield showed that total marketable yields doubled and while yields of high value extra large fruit tripled with irrigation [13]. They found that both extra large and total fruit weight were linearly reduced as irrigation amounts reduced from $0 \%$ cutback reference amount to $45 \%$ cutback amount, while yields of large and medium fruit were nonsignificantly affected. Some studies reported that dry matter, total soluble solids, and blossom end rot were highest for deficit irrigation treatments [27]. Fruit diameter, fruit biomass, yield per plant differed between irrigation treatments [10].

Increased total soluble solute content in tomato fruits with increase in water stress has also been reported in similar studies elsewhere [28, 29]. The fruit TSS content of the stressed treatments was also significantly different between the tomato cultivars with Melkassa Marglobe cultivar having higher total soluble solute content than Melka Shola cultivar. The higher total soluble solute content of Melkassa Marglobe might be the reason why this cultivar is preferred by consumers for use in salads. It has been observed also that small animals and birds prefer to feed on this cultivar than on Melka Shola cultivar.

For processing tomatoes, higher solids content in fruits is a great characteristic as this would reduce the cost of processing [9]. As shown also in Table 6, the dry matter content of the ripe fruit is generally inversely related to the fruit size [30]. The dry matter content was positively related to the total sugar content of the fruit [31]. The tomato fruit is the largest sink for assimilates compared with the rest of the plant's organs [32]. The reduction of fruit size under deficit irrigation was mainly attributed to reduction of water rather than to reduction of assimilates imported into the fruit [32]. This observation might explains why the total soluble solids content of stressed treatments is higher as shown in this study. Farmers aim for high tomato yields while the processing industry wants high fruit quality in terms of high TSS and fruit dry weight concentration and low fruit water content. The higher TSS in stressed

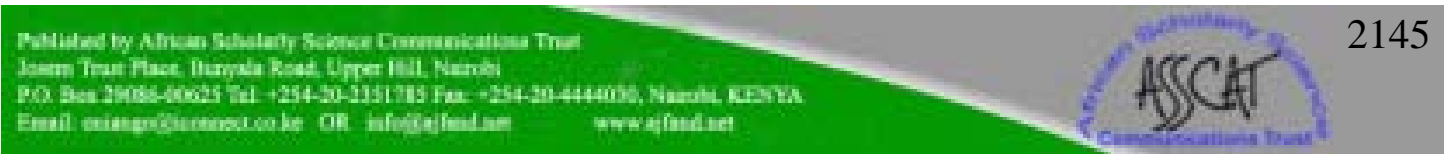


treatments is important for the processing industry. This is justified where water is scarce, or expensive for tomato production.

\section{CONCLUSION}

The results obtained in this study showed that almost all the plant attributes were directly related to water stress level. Irrigation level positively influenced marketable yield of tomato, with tomato yield decreasing as the water deficit level increased. The decrease in yield was reflected in the reduction of the number of fruits per plant and mean fruit weights. Melkassa Marglobe was found to be the cultivar with lower marketable production although the yield difference of the cultivars was statistically non-significant.

A moderate water deficit could significantly improve fruit quality (in terms of TSS content and perhaps acidity) of deficit irrigated tomato of Melka Shola and Melkassa Marglobe by $10 \%$ and $15 \%$, respectively without depressing marketable yields in relation to fully irrigated treatments. Increase in TSS content in fruit grown under soil water deficit condition was related primarily to decrease in fruit water content. Frequent light irrigation improves the size, shape, juiciness and color of the fruit, but total solids (dry matter content) and acid content will be reduced. The decrease in solids will lower the fruit quality for processing. Prolonged water deficit also led to fruit cracking. In selecting the irrigation practices consideration must, therefore, be given to the type of end product required.

The results from of this study can help in the development of water management system for tomato production in the scenario of reduced water availability and enable the tomato growers to produce tomato with optimum yield by allowing little water stress without substantial yield reduction.

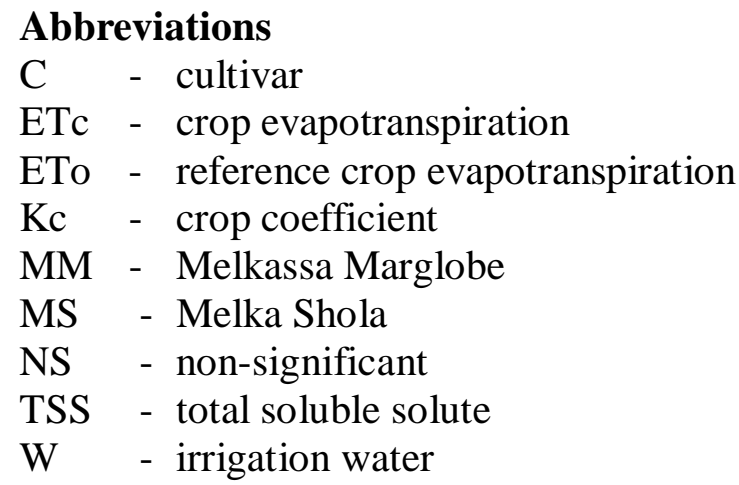




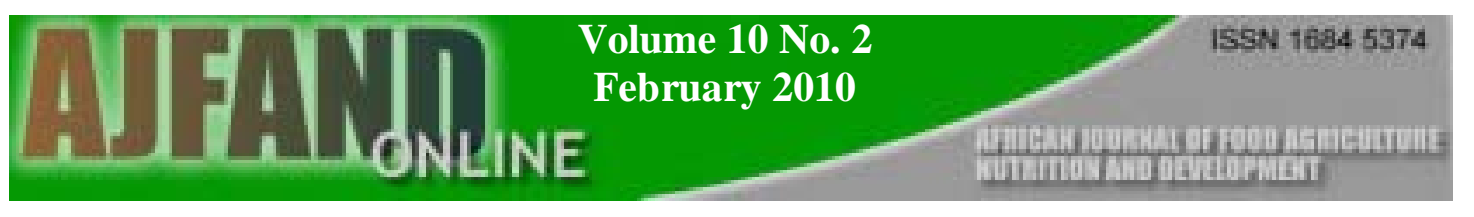

Table 1: Limits used to separate weight classes

\begin{tabular}{lllll}
\hline Cultivars & Ex- large $(\mathrm{g})$ & Large $(\mathrm{g})$ & Medium $(\mathrm{g})$ & Small $(\mathrm{g})$ \\
\hline Melka Shola & $>70$ & $51-70$ & $30-50$ & $<30$ \\
Melkassa Marglobe & $>140$ & $121-140$ & $70-140$ & $<70$ \\
\hline
\end{tabular}

Table 2: ANOVA for effects of cultivar and deficit level on harvest variables

\begin{tabular}{|c|c|c|c|c|c|c|}
\hline Source & \multirow{2}{*}{$\begin{array}{c}\text { Average number } \\
\text { of fruit/plant }\end{array}$} & \multirow{2}{*}{$\begin{array}{c}\text { Average fruit } \\
\text { weight }(\mathrm{g})\end{array}$} & $\begin{array}{l}\text { Harvest } \\
\text { index }\end{array}$ & \multicolumn{2}{l|}{ Number of fruit/plant } & $\begin{array}{l}\text { Sample } \\
\text { fruit size }\end{array}$ \\
\cline { 4 - 7 } & & & & Minimum & Maximum & \\
\hline Cultivar (C) & $27.75^{* *}$ & $67.00^{* *}$ & $62.75 \mathrm{NS}$ & $14.00^{*}$ & $41.50 * *$ & $66.50 * *$ \\
\hline Deficit (W) & $17.89^{* *}$ & $44.33^{* *}$ & $77.00^{* *}$ & $4.94 * *$ & $30.83^{* *}$ & $44.40^{* *}$ \\
\hline $\begin{array}{c}\text { Interaction } \\
\text { (C x W) }\end{array}$ & $22.82^{* *}$ & $55.67 * *$ & $70.23 * *$ & $9.47 \mathrm{NS}$ & $36.16^{* *}$ & $55.45^{* *}$ \\
\hline
\end{tabular}

NS, *, ** non-significant, or significant at $\mathrm{P} \leq 0.05$, or $\mathrm{P} \leq 0.01$.

Table 3: Interaction effects of cultivar and irrigation deficit on harvest variables

\begin{tabular}{|c|c|c|c|c|c|}
\hline \multicolumn{2}{|c|}{ Source $^{\mathrm{z}}$} & \multirow{2}{*}{$\begin{array}{l}\begin{array}{c}\text { Average fruit } \\
\text { weight }(\mathrm{g})^{\mathrm{y}}\end{array} \\
30^{* *}\end{array}$} & \multirow{2}{*}{$\begin{array}{l}\text { Harvest } \\
\text { indices } \\
60.3^{\mathrm{NS}}\end{array}$} & \multirow{2}{*}{$\begin{array}{c}\text { Maximum No of fruit } \\
\text { per plant } \\
59^{* *}\end{array}$} & \multirow{2}{*}{$\begin{array}{c}\begin{array}{c}\text { Smallest fruit } \\
\text { size }(\mathrm{g})\end{array} \\
6.9^{* * *}\end{array}$} \\
\hline 0 & MS & & & & \\
\hline & MM & $104^{* *}$ & $65.2^{\mathrm{NS}}$ & $24^{* *}$ & $35.5^{* *}$ \\
\hline \multirow[t]{2}{*}{25} & MS & $28^{* *}$ & $73.1^{\mathrm{NS}}$ & $50^{* *}$ & $5.9^{* *}$ \\
\hline & MM & $88^{* *}$ & $71.8^{\mathrm{NS}}$ & $23^{* *}$ & $38.7^{* *}$ \\
\hline \multirow[t]{2}{*}{50} & MS & $19^{* *}$ & $78.5^{\mathrm{NS}}$ & $42^{* *}$ & $5.5^{* *}$ \\
\hline & MM & $63^{* *}$ & $73.9^{\mathrm{NS}}$ & $19^{* *}$ & $23.6^{* * *}$ \\
\hline \multirow[t]{2}{*}{75} & MS & $17^{* *}$ & $84.4^{\mathrm{NS}}$ & $37^{* *}$ & $4.4^{* *}$ \\
\hline & MM & $51^{* *}$ & $84.2^{\mathrm{NS}}$ & $14^{* *}$ & $24.1^{* * *}$ \\
\hline
\end{tabular}




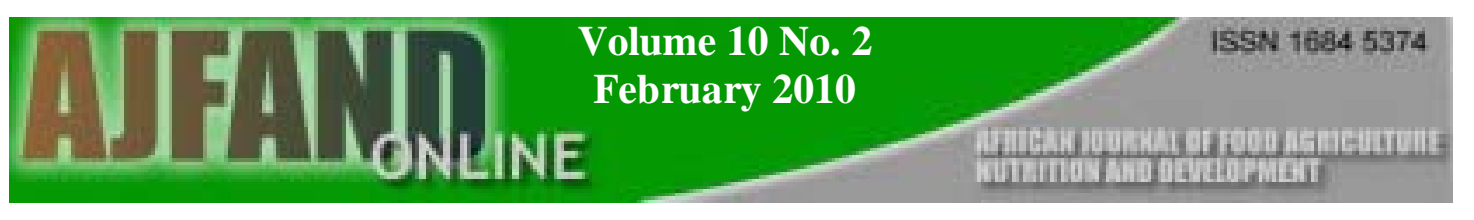

Table 4: ANOVA for the effects of cultivar and water deficit on tomato biomass production

\begin{tabular}{lllllll}
\hline \multicolumn{1}{c}{ Source } & \multicolumn{3}{c}{ Wet weight } & \multicolumn{3}{c}{ Dry weight } \\
\hline Cultivar (C) & Shoot & Fruit & Total & Shoot & Fruit & Total \\
Deficit (W) & $1.173 \mathrm{NS}$ & $5.685 \mathrm{NS}$ & $6.858 \mathrm{NS}$ & $0.23^{* *}$ & $0.434^{*}$ & $0.34^{*}$ \\
Interaction $(\mathrm{CxW})$ & $0.658^{* *}$ & $3.40^{*}$ & $4.065^{* *}$ & $0.124^{* *}$ & $0.49^{* *}$ & $0.618 \mathrm{NS}$ \\
\hline
\end{tabular}

Table 5: ANOVA for effects of cultivar and water deficit on yield and quality of tomato

\begin{tabular}{|l|c|c|c|c|c|}
\hline \multicolumn{1}{|c|}{ Source } & Total Yield & $\begin{array}{c}\text { Marketable } \\
\text { yield }\end{array}$ & Percent loss & $\begin{array}{c}\text { Water } \\
\text { content }\end{array}$ & $\begin{array}{c}\text { Total soluble } \\
\text { solids }\end{array}$ \\
\hline Cultivar $(\mathrm{C})$ & $45.15 \mathrm{NS}$ & $41.4 \mathrm{NS}$ & $7.78 \mathrm{NS}$ & $94.18^{* *}$ & $6.51^{* *}$ \\
\hline Deficit $(\mathrm{W})$ & $27.35^{* *}$ & $24.036^{* *}$ & $13.85^{* *}$ & $80.82^{* *}$ & $7.58^{* *}$ \\
\hline Interaction $(\mathrm{CxW})$ & $36.25 \mathrm{NS}$ & $32.72 \mathrm{NS}$ & $10.82 \mathrm{NS}$ & $87.50 \mathrm{NS}$ & $7.04^{* *}$ \\
\hline
\end{tabular}

Table 6: Interaction effect of cultivar and water deficit on tomato biomass production

\begin{tabular}{lllc}
\hline $\begin{array}{c}\text { Source } \\
\text { Deficit x Cv }\end{array}$ & $\begin{array}{c}\text { Wet shoot } \\
\text { weight }(\mathrm{g})\end{array}$ & $\begin{array}{c}\text { Total soluble } \\
\text { solid }(\%)\end{array}$ \\
\hline 0 & MS & $1.211^{\mathrm{NS}}$ & $6.12^{\mathrm{NS}}$ \\
& $\mathrm{MM}$ & $1.135^{\mathrm{NS}}$ & $6.90^{\mathrm{NS}}$ \\
25 & $\mathrm{MS}$ & $0.812^{\mathrm{NS}}$ & $6.33^{*}$ \\
& $\mathrm{MM}$ & $0.878^{\mathrm{NS}}$ & $7.59^{*}$ \\
50 & $\mathrm{MS}$ & $0.535^{* *}$ & $6.97^{*}$ \\
& $\mathrm{MM}$ & $0.750^{* *}$ & $7.58^{*}$ \\
75 & $\mathrm{MS}$ & $0.502^{\mathrm{NS}}$ & $7.83^{*}$ \\
& $\mathrm{MM}$ & $0.464^{\mathrm{NS}}$ & $9.17^{*}$ \\
\hline
\end{tabular}




\section{REFERENCES}

1. Nuruddin MM, Madramootoo CA and GT Dodds Effects of water stress at different growth stages on greenhouse tomato yield and quality. HortScience, 2003; 38:1389-1393.

2. Benton JJ Tomato plant culture. CRC Press. 1999.

3. Grange RI and J Andrews Expansion rate of young tomato fruit growing on plants at positive water potential. Plant Cell Environment. 1994; 17:181-187.

4. Fereres E and MA Soriano Deficit irrigation for reducing agricultural water use. J. Exp. Bot. 2007; 58:147-159.

5. English MJ and SN Raja Perspectives on deficit irrigation. Agricultural Water Management. 1996; 32:1-14.

6. Kirda C Deficit irrigation scheduling based on plant growth stages showing water stress tolerance. FAO Water Reports. No 22. 2000.

7. Kirda C, Cetin M, Dasgan Y, Topcu S, Kaman H, Ekici B, Derici MR and AI Ozguven Yield response of greenhouse-grown tomato to partial root drying and conventional deficit irrigation. Agricultural Water Management. 2004; 69:191-201.

8. Topcu S, Kirda C, Dasgan Y, Kaman H, Cetin M, Yazici A and MA Bacon Yield response and $\mathrm{N}$-fertilizer recovery of tomato grown under deficit irrigation. Eur. J. Agron. 2006; 26:64-70.

9. Amor MA and FM Amor Response of tomato plants to deficit irrigation under surface or subsurface drip irrigation. Journal of Applied Horticulture. 2007; 9(2):97-100.

10. Savic S, Stikic R, Radovic BV, Bogicevic B, Jovanovic $Z$ and VHT Sukalovic Comparative effects of regulated deficit irrigation (RDI) and partial root-zone drying (PRD) on growth and cell wall peroxidase activity in tomato fruits. Scientia Horticulturae. 2008; 117:15-20.

11. Zegbe JA, Behboudian MH and BE Clothier Response of tomato to partial rootzone drying and deficit irrigation. Rev. Fitotec. Mex. 2007; 30(2):125-131.

12. Zegbe-Dominguez JA, Behboudian MH, Lang A and BE Clothier Deficit irrigation and partial rootzone drying maintain fruit dry mass and enhance fruit quality in 'Petopride' processing tomato (Lycopersicon esculentum, Mill.). Scientia Horticulturae. 2003; 98:505-510. 
13. Smajstrla AG and SJ Locascio Irrigation cutback effects on drip-irrigated tomato yields. Proc. Fla. State Hort. Soc. 1994; 107:113-118.

14. Shanmugavehu KG Production technology of vegetable crops. Oxford Publishing Co. LTD, New Delhi. 1989.

15. Tekinel O, Kanber R, Onder S, Baytorun $\mathbf{N}$ and $\mathbf{R}$ Bastug The effects of trickle and conventional irrigation methods on some crop yields and water use efficiency under Cukurova conditions. Irrigation: Theory and Practice (edited by Rydzewski, J.R. and Ward, C.F.J. 1989) 641-651. Southampton, UK.

16. Jadhew SS, Gutal GB and AA Chougute Cost economics of the drip irrigation system for tomatoes crop. Department of Agricultural Engineering, College of Agriculture, Pune, India. 1990.

17 Banthmore X, Ple Y, Machado JR and BJ Bieche Influence of drip irrigation on the technological characteristics. In: Fifth International Symposium on the Processing Tomatoes. Sorrento, Italy. 1993; 23-27.

18. Kadam JR Evaluation of different irrigation methods for growth and yield of tomatoes. Annals of Plant Physiology. 1993; 7(1):78-84.

19. Tan CS Effect of drip and sprinkler irrigation on yield and quality of the tomatoes cultivars in south eastern Ontario. Canadian Journal of Plant Science. 1995; 75(1):225-230.

20. Shinohara Y, Akiba K, Maruo T and T Ito Effect of water stress on the fruit yield, quality and physiological condition of tomato plants using gravel culture. Acta Hortic. 1995; 396:211-218.

21. Allen R, Pereira LA, Raes D and M Smith Crop evapotranspitation. Irrigation and Drainage Paper No. 56. FAO. Rome. 1998.

22. Doorenbos J and WO Pruitt Crop water requirements. FAO Irrigation and Drain. Paper 24. FAO, Rome. 1977.

23. Gomez KA and AA Gomez Statistical Procedures for Agricultural Research $2^{\text {nd }}$ edn. John Wiley \& Sons, New York, USA. 1984.

24. Nautiyal PC, Joshi YC and D Dayai Response of groundnut to deficit irrigation during vegetative growth. Deficit Irrigation Practices. FAO Water Reports. No 22. 2000.

25. Candido V, Miccolis V, Perniola $M$ and AR Rivelli Water use, water use efficiency and yield response of "Long time storage tomato" (Lycopetsicon esculentum Mill). Proc. 3rd IS Irrigation of Horticultural Crops. Basiliata. Departiento diroduzion vegetale. Universita degli studi della. 2001;789-792 
26. Yaza A, Sezen SM and S Seven Trickle irrigation of cotton in South East Anatolia Project in Turkey. Agricultural Water Management. 2002; 54:189-203.

27. Bhattarai SP and DJ Midmore Influence of soil moisture on yield and quality of tomato on a heavy clay soil. 2002. (available on-line at:

http://www.actahort.org/members/showpdf?booknrarnr (Accessed 17/04/2009).

28. Obreza TA, Pitts DJ, McGovern RJ and TH Spreen Deficit irrigation of micro-irrigated tomato affects yield, fruit quality, and disease severity. No 4626. Florida Agricultural Experimental Station, University of Florida. 2001.

29. Hanson B and D May Drip irrigation increases tomato yields in salt-affected soil of San Joaquin Valley. California Agriculture. 2003; 57(4):132-137.

30. Davies JN and GE Hobson The constituents of tomato fruits: the influence of environment, nutrition and genotype. In: CRC Critical Reviews of Food Science and Nutrition. 1981; 205-280.

31. Ho LC The physiological basis for improving dry matter content and calcium status in tomato fruit. Appl. Agric. Res. 1988; 3:275-281.

32. Ho JC The mechanism of assimilate partitioning and carbohydrate compartmentation in fruit in relation to the quality and yield of tomato. J. Exp. Bot. 1996; 47:1239-1243. 